\section{Wings clipped by economics}

\section{London}

THE Soviet space programme will have severely practical objectives in the next 15 years. The guiding principles during that period will be those of what is called Programme 2005, and will be concentrated in three main areas: the modernization of commercial satellites, wider use of space facilities for research and more manned flights in Earth orbit, according to the government newspaper Pravitelstvennyi Vestnik.

Special emphasis, the newspaper says, will be placed on the satellite monitoring of environmental pollution, satellite broadcasting and satellite emergency rescue systems, as well as map-making and weather forecasting. The manufacture of semiconductors and sophisticated drugs in zero gravity will also have priority status.

During the past 33 years, the paper said, the Soviet Union has spent less than 20,000 million roubles on the development and maintenance of commercial space facilities, while space research has generated some 12,000 million roubles as spin-off. Current annual spending on space is 1,700 million roubles, some "five to ten" times that of the United States, and less than 1 per cent of the All-Union State Budget.

Programme 2005, the report said, will involve the Soviet Ministry of General Machine Building in an outlay of around 6,000 million roubles in 1991-95. This breaks down into 1,000 million roubles for the development and construction of new commercial satellites (excluding their maintenance costs), 2,000 million for research and 3,000 million for manpower costs and new hardware. The newspaper says the programme should produce benefits worth up to 27,000 million roubles - a yield of almost 400 per cent.

The publication of these figures, unprecedented in the history of the Soviet space programme, is not simply an application of glasnost to a previously secret area, but is also relevant to recent debate about the cost of the space programme, for many years a subject of dissident black humour now being openly questioned.

A number of the new People's Deputies have used the new parliamentary procedures to express their doubts that space can ever show the cost-effectiveness which is the basis of Mr Mikhail Gorbachev's economic reforms. The correspondence pages of several leading newspapers have carried plaintive and angry letters asking when all the outlay on communications satellites will supply an efficient telephone service.

Soviet journalists, perhaps piqued that a Japanese citizen will be the first pressman to visit the Mir space station, and only partially mollified by the founding of a journalism contest whose winner will get a similar trip, no longer greet every new launch as an unqualified triumph. Last month, indeed, Izvestiya published a fullpage exposé of the aborted manned Moon programme of the 1960 s, the existence of which was not officially acknowledged during the Brezhnev years.

Then - the unkindest cut of all - Dr Boris Egorov, Director of the Soviet Ministry of Health's Centre for Medical Biotechnology, and the first-ever physician in space, recently took advantage of a Pravda interview to "protest categorically" against the assertion that new medicines can be produced in space, thus calling into question one of the kingpins of Programme-2005.

But Soviet space planners are fighting back with all the weapons that glasnost allows. Major launches, once a secret until after blast-off, are now announced in advance. The commercial value of missions is stressed - the latest manned launch even carried commercial advertising. The Interkosmos joint Comecon programme is now officially commended as a demonstration of Soviet managerial skills and - perhaps in response to the current upsurge of ethnic awareness - the role of non-Russians in the space programme is receiving special mention, from the Ukrainian head of the Baikonur cosmodrome and his Lithuanian on-site political chief down to the 62 ethnic groups represented among the staff at the base.

Vera RIch

\section{Washington}

THE US Postal Service, financially straitened and recently chided by Consumers' Union for its worsening delivery rate, has now had to admit that its knowledge of dinosaur nomenclature is behind the times. At the urging of Congressman George Brown (Democrat, California) a new set of dinosaur stamps will be issued, on 1 October, with a statement to the effect that what the Postal Service says is a Brontosaurus should properly be called an Apatosaurus.

The name Brontosaurus was given by

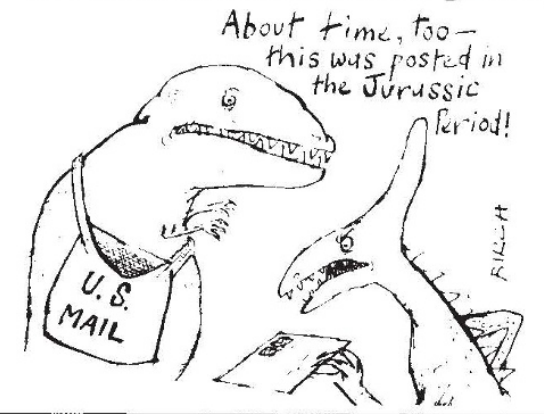

\section{Academics in high office}

\section{London}

POLAND's new minister at the Office of Scientific and Technical Progress is to be Dr Jan Stanislaw Janowski, currently rector of the Academy of Mining and Metallurgy in Krakow. Dr Janowski is a long-standing member of the Democratic Party (SD), one of the two small parties which, for the past 45 years, have voted together with the ruling Polish United Workers' Party. Since 1976, Dr Janowski has represented the SD in the then singlechamber parliament.

In 1982 he found himself in serious trouble with the SD leadership when he refused to vote the party line supporting the outlawing of Solidarity. He returned to party favour only in 1985 , when he became deputy leader of the SD parliamentary group, becoming leader after the "semidemocratic" elections last June.

Last month, when the SD and the equally small Peasant Party (SL) withdrew their support from the Polish United Workers' Party, Janowski was one of the advocates of the coalition which eventually led to the formation of a Solidarity-led government. Janowski will combine ministerial duties with the role of deputy premier.

The education portfolio goes to $\mathrm{Dr}$ Henryk Samsonowicz, a historian, who was elected Rector of Warsaw University under the democratic procedures of the first Solidarity period (1980-1981) - and summarily relieved of that office when Martial Law was declared. Vera RIch

\title{
US Post Office flunks fossil test
}

Charles Marsh to a fossil creature he discovered in Colorado in 1874, and soon became part of every schoolchild's common knowledge. But in 1974 palaeontologists agreed that Marsh's Brontosaurus was identical with a previously discovered dinosaur known as Apatosaurus, and that the prior name should take precedence.

The Postal Service had used the old name deliberately, on the grounds that it is more familiar to most of the population. But Brown was concerned that a generation of schoolchildren would be dangerously confused without official clarification.

David Lindley

- The UK Post Office is being asked - by the Plymouth branch of the British Association - to follow the fashion for dinosaurs on stamps. The occasion is the 150th anniversary, in 1991, of the society's 1841 meeting, when Sir Richard Owen, first director of the Natural History Museum, identified the bones of a large reptile for the first time as Dinosauria. 